\title{
Effects of long-term fertilization on oxidizable organic carbon fractions on the Loess Plateau, China
}

\author{
DING Shaonan ${ }^{1}$, XUE Sha $^{1,2}$, LIU Guobin ${ }^{1,2^{*}}$ \\ ${ }^{1}$ College of Natural Resources and Environment, Northwest A\&F University, Yangling 712100, China; \\ ${ }^{2}$ Institute of Soil and Water Conservation, Chinese Academy of Sciences and Ministry of Water Resources, Yangling 712100 , \\ China
}

\begin{abstract}
The effects of long-term fertilization on pools of soil organic carbon (SOC) have been well studied, but limited information is available on the oxidizable organic carbon (OOC) fractions, especially for the Loess Plateau in China. We evaluated the effects of a 15-year fertilization on the OOC fractions (F1, F2, F3 and F4) in the $0-20$ and $20-40 \mathrm{~cm}$ soil layers in flat farmland under nine treatments ( $N$ (nitrogen, urea), $P$ (phosphorus, monocalcium phosphate), $M$ (organic fertilizer, composted sheep manure), N+P (NP), $M+N(M N), M+P(M P), M+N+P(M N P), C K$ (control, no fertilizer) and bare land (BL, no crops or fertilizer)). SOC content increased more markedly in the treatment containing manure than in those with inorganic fertilizers alone. F1, F2, F4 and F3 accounted for $47 \%, 27 \%, 18 \%$ and $8 \%$ of total organic carbon, respectively. F1 was a more sensitive index than the other $\mathrm{C}$ fractions in the sensitivity index $(\mathrm{SI})$ analysis. F1 and $\mathrm{F} 2$ were highly correlated with total nitrogen (TN) and available nitrogen (AN), F3 was negatively correlated with $\mathrm{pH}$ and $\mathrm{F} 4$ was correlated with $\mathrm{TN}$. A cluster analysis showed that the treatments containing manure formed one group, and the other treatments formed another group, which indicated the different effects of fertilization on soil properties. Long-term fertilization with inorganic fertilizer increased the F4 fraction while manure fertilizer not only increased labile fractions (F1) in a short time, but also increased passive fraction (F4) over a longer term. The mixed fertilizer mainly affected F3 fraction. The study demonstrated that manure fertilizer was recommended to use in the farmland on the Loess Plateau for the long-term sustainability of agriculture.
\end{abstract}

\section{Keywords: long-term fertilization; oxidizable organic carbon fractions; farmland soil; Loess Plateau}

Citation: DING Shaonan, XUE Sha, LIU Guobin. 2016. Effects of long-term fertilization on oxidizable organic carbon fractions on the Loess Plateau, China. Journal of Arid Land, 8(4): 579-590. doi: 10.1007/s40333-016-0007-x

Because soil organic carbon (SOC) in agricultural soils has a turnover time from decades to centuries, the gross contents of SOC change very slowly (Stevenson, 1994). As a result, the measurement of SOC alone does not adequately reflect the changes in soil quality and nutrient status (Bolinder et al., 1999; Banger et al., 2010; Liu et al., 2010). Identifying alternative C fractions that are more sensitive or indicative of changes in $\mathrm{C}$ contents than SOC would, therefore, be useful (Wang and Wang, 2011; Zhang et al., 2012). Oxidizable organic carbon (OOC) has received researchers' attention due to its sensitivity and ease of detection, which characterizes SOC both quality and quantity (Barreto et al., 2011). Chan et al. (2001) proposed a modified procedure based on Walkley-Black method (Walkley, 1947), which only uses half amount of

\footnotetext{
*Corresponding author: LIU Guobin (E-mail: gbliu@ms.iswc.ac.cn)

Received 2015-09-09; revised 2016-03-10; accepted 2016-03-16

(C) Xinjiang Institute of Ecology and Geography, Chinese Academy of Sciences, Science Press and Springer-Verlag Berlin Heidelberg 2016
} 
sulfuric acid, is a more sensitive indicator for the improvement in soil quality parameters, and can separate OOC into four fractions (F1, F2, F3 and F4) by its degree of oxidation. The use of modified Walkley-Black procedure is well documented in different regions (Majumder et al., 2007, 2008; Xavier et al., 2009; Barreto et al., 2011; Bhattacharyya et al., 2011). The fractions F1 and F2 are associated with the availability of nutrients and the formation of macro-aggregates (Chan et al., 2001). F1 is the most labile fraction in soil and is highly correlated with the free light fraction of soil organic matter (SOM) (Maia et al., 2007). F3 and F4, however, are associated with compounds of greater chemical stability and higher molecular weight which originate from the decomposition and humification of SOM (Guareschi et al., 2013).

OOC, like SOC, is influenced by many factors, such as soil parental material, climatic conditions, land use and cover change (Lefroy et al., 1993; Campbell et al., 1996; Verma et al., 2010; Zhang et al., 2012, 2013). The ratios of the four fractions differ in different types of ecosystems, and changes in the use of soils or the state of the vegetation may quickly alter the processes of the accumulation or loss of organic matter in soils, thereby affecting the total amount of carbon stored (Patra et al., 2014). Chan et al. (2001) compared the effectiveness of different pasture species in maintaining OOC fractions in a semi-arid region of Australia, and other studies subsequently explored OOC changes in various agro-ecosystems in different regions (Chan et al., 2002; Loss et al., 2010; Bhattacharyya et al., 2011; Pereira et al., 2013). The effects of fertilization on OOC fractions in farmland soil, however, have been rarely studied, especially the changes over varying durations of fertilization. Long-term field experiments can overcome the effects of inter-annual climatic variation on soil fertility (Yang et al., 2006) and provide critical insights into factors that influence SOC management and their contributions to agricultural sustainability (Rasmussen et al., 1998).

The semi-arid Loess Plateau is a highly fragile ecosystem where the soil has degraded over vast areas in recent decades (Shi and Shao, 2000). Dryland farming has prevailed for several decades in this region. The main soils of the Loess Plateau develop from calcareous loessial parental material and have low SOC contents, likely due to the dry climate, sparse vegetation and intensive farming (Janzen et al., 1997). For improving the ecological environment, the Chinese government launched the nationwide "Grain for Green" project in 1999, which converted unsuitable sloping farmland to forests or grassland (Zhang et al., 2011). The flat farmland between valleys has thus become of great importance to regional farming due to the loss of the sloped farmland. Low soil fertility, however, is hindering dryland farming on the Loess Plateau, so fertilization is required to guarantee yields (He and Lin, 1992), which consequently affects the soil properties (Fan et al., 2008, Liu et al., 2010). The study of the influence of fertilization on the SOC and OOC fractions in this special region has been neglected.

We thus hypothesized that various types of fertilization would differentially influence the SOC and OOC fractions. We tested this hypothesis with a 15-year fertilization experiment in the farmland on the Loess Plateau. Our objective was to compare the effects of various fertilizations on the OOC fractions and related soil properties for identifying the best practice influencing labile $\mathrm{OC}$ fractions and the regional farming activity.

\section{Materials and methods}

\subsection{Study area}

The study was carried out at the Ansai Station of the Northwest Institute of Soil and Water Conservation, Chinese Academy of Sciences and Ministry of Water Resource in northern Shaanxi province, a typically hilly region of the Loess Plateau $\left(36^{\circ} 51^{\prime} 30^{\prime \prime} \mathrm{N}, 109^{\circ} 19^{\prime} 23^{\prime \prime} \mathrm{E} ; 1,032 \mathrm{~m}\right.$ asl). This semi-arid region has a gully density of $4.2-8.0 \mathrm{~km} / \mathrm{km}^{2}$ and erosion rate of $13.5 \times 10^{3}$ $\mathrm{t} /\left(\mathrm{km}^{2} \cdot \mathrm{a}\right)$. The climate is warm and temperate with an annual mean temperature of $8.8^{\circ} \mathrm{C}$, accumulated temperature of $3,114^{\circ} \mathrm{C}\left(\geq 10^{\circ} \mathrm{C}\right)$, a frost-free period of $159 \mathrm{~d}, 2,416 \mathrm{~h}$ of sunshine annually and total radiation of $548 \times 10^{3} \mathrm{~J} / \mathrm{cm}^{2}$. Annual precipitation, evaporation and aridity index are $535 \mathrm{~mm}, 146 \mathrm{~mm}$ and 1.46, respectively. The soil is mainly wind-deposited Huangmian soil, characterized by a yellow color, an absence of bedding, a silty texture, looseness and 
wetness-induced collapsibility (Zhang et al., 2011). The vegetation of the region belongs to the temperate forest steppe, but the original vegetation has been destroyed. Because there is no irrigation conditions, the farmland just rely on natural rainfall.

\subsection{Experimental design}

Experimental plots were established in 1997 for investigating the effects of fertilization on soil properties. The crop was planted in soybean-corn rotation, and it became corn in 2011. Before the plots, the land was planted to millet. The plots were $2.33 \mathrm{~m} \times 6 \mathrm{~m}$ in size and were arranged in a completely randomized block design with three replicates of nine treatments: $\mathrm{N}$ (nitrogen, urea), $\mathrm{P}$ (phosphorus, monocalcium phosphate), $\mathrm{M}$ (organic fertilizer, sheep manure, $\mathrm{C} / \mathrm{N}=15), \mathrm{N}+\mathrm{P}(\mathrm{NP})$, $\mathrm{M}+\mathrm{N}(\mathrm{MN}), \mathrm{M}+\mathrm{P}(\mathrm{MP}), \mathrm{M}+\mathrm{N}+\mathrm{P}(\mathrm{MNP}), \mathrm{CK}$ (control, no fertilizer), and bare land (BL, no crops or fertilizer). Every two plots were separated by a $0.5-\mathrm{m}$ strip. All plots were managed in the same way except fertilization treatment. The rates of $\mathrm{N}, \mathrm{P}$ and manure fertilization were 97.5, 75 and 7,500 $\mathrm{kg} / \mathrm{hm}^{2}$, respectively. The manure and phosphate fertilizer were applied once as the seed fertilizer, and $20 \%$ of the urea was applied as a seed fertilizer, the remaining $80 \%$ of urea was applied during the bell-mouthed and tasselling stages. Weeding was done twice. Corn (Zea mays L., cultivar Shuang-hui II) was planted on 27 April and harvested on 19 October 2011. Row spacing and plant spacing was $58 \mathrm{~cm} \times 35 \mathrm{~cm}$.

\subsection{Soil sampling and analysis}

Five soil samples were collected and bulked after the harvest with a core sampler using the S-sampling method from the $0-20$ and $20-40 \mathrm{~cm}$ layers. The samples were packed in fabric bags, immediately transported to the laboratory, air-dried at room temperature, ground and sequentially passed through 2-, 1 - and $0.25-\mathrm{mm}$ sieves for the analysis of physical and chemical properties and the content of OOC fractions.

The physical-chemical properties were analyzed using standard procedures of the Chinese Ecosystem Research Network (Editorial Committee, 1996) and the Soil Science Society of China (1999). SOM content was determined by wet digestion with a mixture of potassium dichromate and concentrated sulfuric acid, and total organic carbon (TOC) content was calculated as SOM/1.724. Total $\mathrm{N}(\mathrm{TN})$ content was measured by the semi-micro Kjeldahl method, and total P (TP) content was colorimetrically determined by wet digestion with $\mathrm{H}_{2} \mathrm{SO}_{4}+\mathrm{HClO}_{4}$. Available $\mathrm{N}$ content (AN) was determined with a micro-diffusion technique after alkaline hydrolysis. Available P (AP) content was determined by the Olsen method. Soil pH was determined by an automatic titrator in 1:2.5 soil:water suspensions (Wang et al., 2012). The results are shown in Table 1.

The OOC fractions were determined by a modified Walkley-Black method (Walkley and Black, 1934) as described by Chan et al. (2001) using 5, 10 and $20 \mathrm{~mL}$ of concentrated $\mathrm{H}_{2} \mathrm{SO}_{4}$ to produce three acid-aqueous solutions of $0.5: 1,1: 1$ and $2: 1$ (corresponding to 6,9 and $12 \mathrm{~mol} / \mathrm{L}$ $\mathrm{H}_{2} \mathrm{SO}_{4}$, respectively), separating TOC into the following four fractions of variable oxidizability: $\mathrm{F} 1$, OOC under $6 \mathrm{~mol} / \mathrm{L} \mathrm{H}_{2} \mathrm{SO}_{4}$; F2, the difference in OOC extracted between 6 and $9 \mathrm{~mol} / \mathrm{L}$ $\mathrm{H}_{2} \mathrm{SO}_{4} ; \mathrm{F} 3$, the difference in OOC extracted between 9 and $12 \mathrm{~mol} / \mathrm{L} \mathrm{H}_{2} \mathrm{SO}_{4}$. The $12 \mathrm{~mol} / \mathrm{L}$ $\mathrm{H}_{2} \mathrm{SO}_{4}$ is equivalent to the standard Walkley-Black method; F4, residual organic carbon after reaction with $12 \mathrm{~mol} / \mathrm{L} \mathrm{H}_{2} \mathrm{SO}_{4}$.

A sensitivity index (SI) for identifying the best SOC indicator was calculated for each $\mathrm{C}$ fraction as:

$$
\mathrm{SI}=\left(\mathrm{C}_{\text {fraction in fertilization }}-\mathrm{C}_{\text {fraction in control }}\right) / \mathrm{C}_{\text {fraction in control }} \times 100 \text {, }
$$

The $\mathrm{C}$ content in $\mathrm{F} 1$ was considered labile $\mathrm{C}\left(\mathrm{C}_{\mathrm{L}}\right)$, and the non-labile $\mathrm{C}\left(\mathrm{C}_{\mathrm{NL}}\right)$ was determined by $\mathrm{C}_{\mathrm{NL}}=\mathrm{SOC}-\mathrm{C}_{\mathrm{L}}$. We calculated the following indices based on differences in $\mathrm{C}$ content between the fertilization and control treatments:

$$
\mathrm{CPI}=\mathrm{C}_{\text {fertilization }} / \mathrm{C}_{\mathrm{CK}} \text {, }
$$

Lability $(\mathrm{L})=\mathrm{C}_{\mathrm{L}} / \mathrm{C}_{\mathrm{NL}}$,

Lability Index $(\mathrm{LI})=\mathrm{L}_{\text {fertilization }} / \mathrm{L}_{\mathrm{CK}}$,

Carbon Management Index $(\mathrm{CMI})=\mathrm{CPI} \times \mathrm{LI} \times 100$. 


\subsection{Data analysis}

All statistical analyses were performed with SPSS for Windows (version 13.0), and analysis of variance was performed using ANOVA procedure. The treatment means were compared using least significant differences (LSD) $(P<0.05)$. Relationships between the $\mathrm{C}$ fractions and the soil physical-chemical properties were compared by correlation analysis $(n=27)$. A cluster analysis was also conducted using SPSS.

Table 1 Soil properties of different fertilization treatments in the 0-20 and 20-40 cm soil layers

\begin{tabular}{|c|c|c|c|c|c|c|c|}
\hline Index & $\begin{array}{l}\text { Soil } \\
\text { layer } \\
(\mathrm{cm})\end{array}$ & $\begin{array}{l}\text { Organic matter } \\
(\mathrm{g} / \mathrm{kg})\end{array}$ & $\begin{array}{l}\text { Total N } \\
(\mathrm{g} / \mathrm{kg})\end{array}$ & $\begin{array}{l}\text { Total P } \\
(\mathrm{g} / \mathrm{kg})\end{array}$ & $\begin{array}{l}\text { Available N } \\
(\mathrm{mg} / \mathrm{kg})\end{array}$ & $\begin{array}{l}\text { Available P } \\
(\mathrm{mg} / \mathrm{kg})\end{array}$ & $\mathrm{pH}$ \\
\hline \multirow{2}{*}{ BL } & $0-20$ & $9.75 \pm 0.01^{\mathrm{d}}$ & $0.56 \pm 0.07^{\mathrm{b}}$ & $0.65 \pm 0.03^{\mathrm{c}}$ & $43.6 \pm 0.94^{\mathrm{b}}$ & $8.01 \pm 1.99^{c}$ & $8.57 \pm 0.02^{\mathrm{abc}}$ \\
\hline & $20-40$ & $6.71 \pm 0.35^{\mathrm{B}}$ & $0.44 \pm 0.06^{\mathrm{BCD}}$ & $0.57 \pm 0.02^{\mathrm{C}}$ & $24.6 \pm 5.21^{\mathrm{BC}}$ & $3.03 \pm 0.24^{\mathrm{B}}$ & $8.68 \pm 0.03^{\mathrm{B}}$ \\
\hline \multirow{2}{*}{ CK } & $0-20$ & $10.66 \pm 0.12^{\mathrm{c}}$ & $0.60 \pm 0.13^{\mathrm{b}}$ & $0.64 \pm 0.03^{\mathrm{c}}$ & $35.2 \pm 5.67^{\mathrm{c}}$ & $2.91 \pm 0.95^{\mathrm{d}}$ & $8.60 \pm 0.01^{\mathrm{a}}$ \\
\hline & $20-40$ & $6.92 \pm 0.46^{\mathrm{B}}$ & $0.45 \pm 0.05^{\mathrm{ABCD}}$ & $0.58 \pm 0.01^{\mathrm{BC}}$ & $21.8 \pm 1.77^{\mathrm{C}}$ & $1.38 \pm 0.10^{\mathrm{B}}$ & $8.74 \pm 0.05^{\mathrm{A}}$ \\
\hline \multirow{2}{*}{$\mathrm{N}$} & $0-20$ & $10.31 \pm 0.39^{\mathrm{cd}}$ & $0.59 \pm 0.01^{\mathrm{b}}$ & $0.64 \pm 0.01^{\mathrm{c}}$ & $39.7 \pm 8.59^{\mathrm{bc}}$ & $2.57 \pm 0.70^{\mathrm{d}}$ & $8.55 \pm 0.02^{\text {bcd }}$ \\
\hline & $20-40$ & $6.86 \pm 0.05^{\mathrm{B}}$ & $0.43 \pm 0.04^{\mathrm{D}}$ & $0.58 \pm 0.01^{\mathrm{BC}}$ & $27.6 \pm 1.26^{\mathrm{AB}}$ & $1.35 \pm 0.42^{\mathrm{B}}$ & $8.74 \pm 0.04^{\mathrm{A}}$ \\
\hline \multirow{2}{*}{$P$} & $0-20$ & $11.01 \pm 0.44^{\mathrm{c}}$ & $0.64 \pm 0.04^{\mathrm{b}}$ & $0.82 \pm 0.04^{\mathrm{ab}}$ & $36.1 \pm 3.22^{\mathrm{c}}$ & $22.01 \pm 3.43^{b}$ & $8.46 \pm 0.01^{\mathrm{e}}$ \\
\hline & $20-40$ & $6.56 \pm 0.73^{\mathrm{B}}$ & $0.44 \pm 0.01^{\mathrm{CD}}$ & $0.60 \pm 0.03^{\mathrm{AB}}$ & $22.4 \pm 3.16^{\mathrm{C}}$ & $2.58 \pm 1.65^{\mathrm{B}}$ & $8.74 \pm 0.02^{\mathrm{A}}$ \\
\hline \multirow{2}{*}{ NP } & $0-20$ & $10.64 \pm 0.33^{\mathrm{cd}}$ & $0.62 \pm 0.02^{\mathrm{b}}$ & $0.80 \pm 0.05^{\mathrm{bc}}$ & $37.2 \pm 5.21^{\mathrm{c}}$ & $18.01 \pm 2.56^{\mathrm{b}}$ & $8.61 \pm 0.03^{\mathrm{a}}$ \\
\hline & $20-40$ & $6.57 \pm 0.21^{\mathrm{B}}$ & $0.44 \pm 0.03^{\mathrm{CD}}$ & $0.59 \pm 0.02^{\mathrm{B}}$ & $24.0 \pm 5.17^{\mathrm{BC}}$ & $2.83 \pm 0.74^{\mathrm{B}}$ & $8.72 \pm 0.01^{\mathrm{AB}}$ \\
\hline \multirow{2}{*}{ M } & $0-20$ & $14.54 \pm 0.57^{\mathrm{ab}}$ & $0.86 \pm 0.06^{\mathrm{a}}$ & $0.68 \pm 0.01^{\mathrm{c}}$ & $54.1 \pm 7.06^{\mathrm{a}}$ & $5.9 \pm 0.79^{\text {cd }}$ & $8.53 \pm 0.02^{\text {cd }}$ \\
\hline & $20-40$ & $7.73 \pm 0.16^{\mathrm{A}}$ & $0.49 \pm 0.02^{\mathrm{AB}}$ & $0.60 \pm 0.02^{\mathrm{AB}}$ & $29.5 \pm 4.87^{\mathrm{A}}$ & $2.07 \pm 0.15^{\text {B }}$ & $8.73 \pm 0.01^{\mathrm{A}}$ \\
\hline \multirow{2}{*}{$\mathrm{MN}$} & $0-20$ & $15.21 \pm 0.26^{\mathrm{a}}$ & $0.83 \pm 0.05^{\mathrm{a}}$ & $0.66 \pm 0.02^{\mathrm{c}}$ & $55.8 \pm 0.64^{\mathrm{a}}$ & $5.41 \pm 0.87^{\mathrm{cd}}$ & $8.52 \pm 0.06^{\mathrm{d}}$ \\
\hline & $20-40$ & $7.69 \pm 0.48^{\mathrm{A}}$ & $0.48 \pm 0.01^{\mathrm{ABC}}$ & $0.60 \pm 0.03^{\mathrm{AB}}$ & $27.7 \pm 5.01^{\mathrm{AB}}$ & $1.80 \pm 0.20^{\mathrm{B}}$ & $8.75 \pm 0.01^{\mathrm{A}}$ \\
\hline \multirow{2}{*}{ MP } & $0-20$ & $14.16 \pm 1.32^{\mathrm{ab}}$ & $0.85 \pm 0.02^{\mathrm{a}}$ & $0.88 \pm 0.10^{\mathrm{a}}$ & $55.7 \pm 2.60^{\mathrm{a}}$ & $45.19 \pm 2.32^{\mathrm{a}}$ & $8.59 \pm 0.02^{\mathrm{ab}}$ \\
\hline & $20-40$ & $7.27 \pm 0.78^{\mathrm{AB}}$ & $0.48 \pm 0.02^{\mathrm{ABCD}}$ & $0.60 \pm 0.01^{\mathrm{AB}}$ & $27.4 \pm 2.03^{\mathrm{AB}}$ & $6.68 \pm 3.22^{\mathrm{A}}$ & $8.74 \pm 0.02^{\mathrm{A}}$ \\
\hline \multirow{2}{*}{ MNP } & $0-20$ & $13.80 \pm 0.17^{\mathrm{b}}$ & $0.83 \pm 0.10^{\mathrm{a}}$ & $0.83 \pm 0.07^{\mathrm{ab}}$ & $53.2 \pm 3.73^{\mathrm{a}}$ & $40.97 \pm 6.24^{\mathrm{a}}$ & $8.57 \pm 0.03^{\mathrm{abc}}$ \\
\hline & $20-40$ & $7.68 \pm 0.40^{\mathrm{A}}$ & $0.49 \pm 0.03^{\mathrm{A}}$ & $0.61 \pm 0.03^{\mathrm{A}}$ & $30.3 \pm 4.11^{\mathrm{A}}$ & $6.47 \pm 0.28^{\mathrm{A}}$ & $8.75 \pm 0.01^{\mathrm{A}}$ \\
\hline
\end{tabular}

Note: Means with lowercase and capital letters within a column indicate significantly different in the 0-20 and 20-40 cm soil layers at $P<0.05$ level. Mean \pm SD ( $n=3)$. BL, bare land; CK, control; N, nitrogen; P, phosphorus; M, organic fertilizer. NP, MN, MP and MNP indicate the combination of different fertilizers. The following abbreviations are the same.

\section{Results}

\subsection{SOC}

The SOC content was higher in the $0-20 \mathrm{~cm}$ layer than in the $20-40 \mathrm{~cm}$ layer for all treatments (Table 2), and varied from 5.98 to $8.82 \mathrm{~g} / \mathrm{kg}$ in the $0-20 \mathrm{~cm}$ layer and from 3.64 to $4.46 \mathrm{~g} / \mathrm{kg}$ in the 20-40 cm layer. The average SOC content in the treatments with inorganic fertilizers was 6.18 $\mathrm{g} / \mathrm{kg}$, with the lowest content in the $\mathrm{N}$ treatment $(5.98 \mathrm{~g} / \mathrm{kg})$. SOC contents did not differ significantly between $\mathrm{CK}$ and the treatments containing only inorganic fertilizers. In contrast, SOC contents were significantly higher in the treatments containing manure than in CK by an average of $35 \%$ in the $0-20 \mathrm{~cm}$ layer and of $9 \%$ in the $20-40 \mathrm{~cm}$ layer.

\subsection{OOC fractions}

The fractions of F1, F2 and F4 were the lowest in the 0-20 cm layer in BL, with F3 similar in all fertilization treatments except NP and MN treatments. F1, F2 and F4 were not significantly higher 
in the treatments containing only inorganic fertilizers than in $\mathrm{CK}$, but $\mathrm{F} 1$ and $\mathrm{F} 2$ were significantly higher in the treatments containing manure. F3 was significantly higher than in CK in only $\mathrm{M}$ and $\mathrm{MN}$ treatments. F4 was significantly higher in $\mathrm{MN}$ than in $\mathrm{CK}$, with the other treatments varying only slightly.

F1 was significantly higher in the subsurface layer in MN and MNP treatments than in CK, and F2 was significantly higher in the treatments containing manure, except the MN treatment. F3, however, did not differ significantly between the organic and inorganic treatments. F4 also did not differ significantly but was the lowest in P treatment and highest in MN treatment (Table 2).

Table 2 The oxidizable organic carbon fractions and soil organic carbon content in the 0-20 and 20-40 cm soil layers

\begin{tabular}{|c|c|c|c|c|c|c|c|c|c|c|}
\hline \multirow{2}{*}{ Treatment } & \multicolumn{2}{|c|}{$\mathrm{F} 1(\mathrm{~g} / \mathrm{kg})$} & \multicolumn{2}{|c|}{ F2 (g/kg) } & \multicolumn{2}{|c|}{ F3 (g/kg) } & \multicolumn{2}{|c|}{ F4 (g/kg) } & \multicolumn{2}{|c|}{$\mathrm{SOC}(\mathrm{g} / \mathrm{kg})$} \\
\hline & $0-20 \mathrm{~cm}$ & $20-40 \mathrm{~cm}$ & $0-20 \mathrm{~cm}$ & $20-40 \mathrm{~cm}$ & $0-20 \mathrm{~cm}$ & $20-40 \mathrm{~cm}$ & $0-20 \mathrm{~cm}$ & $20-40 \mathrm{~cm}$ & $0-20 \mathrm{~cm}$ & $20-40 \mathrm{~cm}$ \\
\hline $\begin{array}{c}\text { Value in } \\
1997\end{array}$ & 2.68 & 1.88 & 1.48 & 1.05 & 0.48 & 0.65 & 0.92 & 0.53 & 5.57 & 4.12 \\
\hline $\mathrm{BL}$ & $2.63^{d}$ & $1.80^{\mathrm{cd}}$ & $1.53^{\mathrm{c}}$ & $0.95^{\text {cde }}$ & $0.56^{\mathrm{bc}}$ & $0.43^{\mathrm{a}}$ & $0.94^{\mathrm{d}}$ & $0.72^{\mathrm{bc}}$ & $5.66^{\mathrm{d}}$ & $3.89^{\text {cd }}$ \\
\hline $\mathrm{CK}$ & $2.77^{\mathrm{cd}}$ & $1.84^{\text {bcd }}$ & $1.71^{\mathrm{bc}}$ & $0.93^{\mathrm{de}}$ & $0.44^{\mathrm{cd}}$ & $0.39^{\mathrm{ab}}$ & $1.27^{\mathrm{bc}}$ & $0.84^{\mathrm{ab}}$ & $6.18^{\mathrm{cd}}$ & $4.01^{\mathrm{bcd}}$ \\
\hline $\mathrm{N}$ & $2.83^{\mathrm{cd}}$ & $1.84^{\text {bcd }}$ & $1.59^{\mathrm{c}}$ & $1.00^{\text {bcde }}$ & $0.46^{\mathrm{cd}}$ & $0.41^{\mathrm{ab}}$ & $1.10^{\mathrm{cd}}$ & $0.73^{\mathrm{bc}}$ & $5.98^{\mathrm{cd}}$ & $3.98^{\mathrm{bcd}}$ \\
\hline $\mathrm{P}$ & $2.97^{\mathrm{c}}$ & $1.78^{\mathrm{cd}}$ & $1.61^{\mathrm{c}}$ & $0.89^{\mathrm{e}}$ & $0.64^{\mathrm{b}}$ & $0.37^{\mathrm{ab}}$ & $1.16^{\mathrm{bcd}}$ & $0.60^{\mathrm{c}}$ & $6.38^{\mathrm{c}}$ & $3.64^{\mathrm{d}}$ \\
\hline NP & $2.64^{\mathrm{d}}$ & $1.65^{\mathrm{d}}$ & $1.96^{\mathrm{b}}$ & $1.12^{\mathrm{abcd}}$ & $0.40^{\mathrm{d}}$ & $0.32^{\mathrm{ab}}$ & $1.16^{\mathrm{bcd}}$ & $0.72^{\mathrm{bc}}$ & $6.17^{\mathrm{cd}}$ & $3.82^{\mathrm{cd}}$ \\
\hline M & $4.29^{\mathrm{a}}$ & $2.03^{\mathrm{ab}}$ & $2.37^{\mathrm{a}}$ & $1.20^{\mathrm{ab}}$ & $0.69^{\mathrm{b}}$ & $0.42^{\mathrm{a}}$ & $1.09^{\mathrm{cd}}$ & $0.72^{\mathrm{bc}}$ & $8.43^{\mathrm{ab}}$ & $4.37^{\mathrm{ab}}$ \\
\hline $\mathrm{MN}$ & $4.01^{\mathrm{b}}$ & $2.05^{\mathrm{a}}$ & $2.37^{\mathrm{a}}$ & $1.10^{\mathrm{abcd}}$ & $0.86^{\mathrm{a}}$ & $0.37^{\mathrm{ab}}$ & $1.58^{\mathrm{a}}$ & $0.94^{\mathrm{a}}$ & $8.82^{\mathrm{a}}$ & $4.46^{\mathrm{a}}$ \\
\hline MP & $4.02^{\mathrm{b}}$ & $1.97^{\mathrm{abc}}$ & $2.40^{\mathrm{a}}$ & $1.22^{\mathrm{a}}$ & $0.44^{\text {cd }}$ & $0.26^{\mathrm{b}}$ & $1.35^{\mathrm{b}}$ & $0.76^{\mathrm{bc}}$ & $8.21^{\mathrm{b}}$ & $4.21^{\mathrm{abc}}$ \\
\hline MNP & $3.82^{\mathrm{b}}$ & $2.05^{\mathrm{a}}$ & $2.31^{\mathrm{a}}$ & $1.14^{\mathrm{abc}}$ & $0.50^{\mathrm{cd}}$ & $0.38^{\mathrm{ab}}$ & $1.38^{\mathrm{ab}}$ & $0.87^{\mathrm{ab}}$ & $8.01^{\mathrm{b}}$ & $4.45^{\mathrm{a}}$ \\
\hline
\end{tabular}

Note: Means with the same letter within a column are not significantly different at $P<0.05$ level.

The percentage of $\mathrm{F} 1$ accounting for TOC was the largest under all treatments and varied from $43 \%$ to $51 \%$ (Fig. 1). When manure was applied alone, F1 percentage significantly increased in the $0-20$ $\mathrm{cm}$ layer, and the percentage of F4 declined correspondingly. Little difference was found in the other two fractions. However, the percentage of F1 declined in the NP treatment compared with other treatments. The four fractions F1, F2, F4 and F3 accounted for 47\%, 27\%, 18\% and 8\% of TOC, respectively.

NP, MN and MP had significant effects on F3 $(P<0.05$; Table 3$)$, indicating that these fertilizers had an interactive effect and mainly influenced F3 in the $0-20 \mathrm{~cm}$ layer and that MN

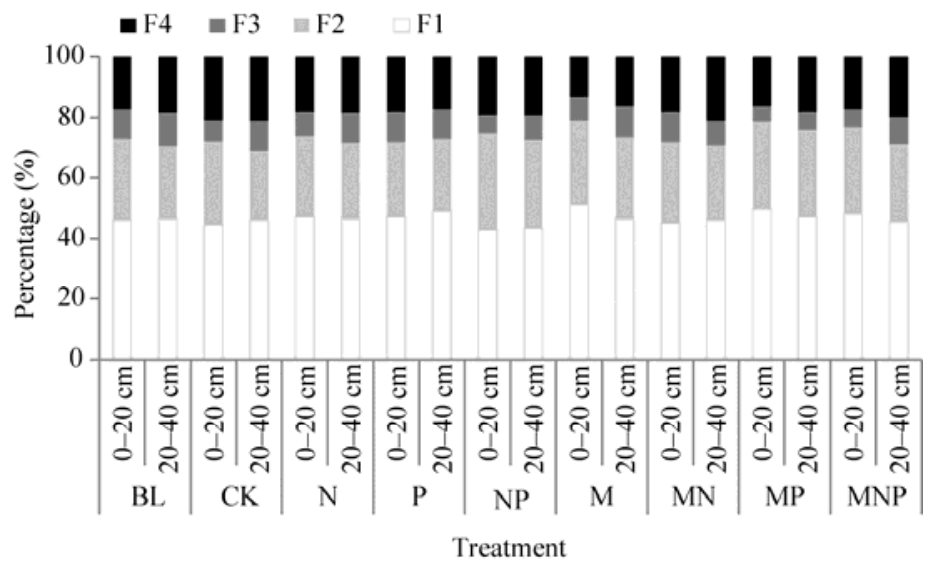

Fig. 1 The percentage of OOC fractions (F1-F4) accounting for TOC under different fertilization treatments 
and MNP treatments had an interactive effect on F4. In the $20-40 \mathrm{~cm}$ layer, only MN had an interactive effect on $\mathrm{F} 2$.

\subsection{Sensitivity index of OOC and SOC}

Sensitivity index (SI) of the OOC fractions significantly differed among the treatments (Fig. 2). In the 0-20 cm layer, the SI of organic fertilizer involved was greater than inorganic fertilizer as a whole. SI of F1 and F2 seemed more sensitive than SOC, especially in the treatments with organic fertilizer. SI was the highest for F2 in the $20-40 \mathrm{~cm}$ layer. The application of $\mathrm{P}$ fertilizer had an adverse effect on SI in all fractions.

Table 3 Interaction of N, P and M fertilizers on SOC and OOC fractions

\begin{tabular}{|c|c|c|c|c|c|c|c|c|}
\hline Soil layer $(\mathrm{cm})$ & & $\mathrm{N}$ & $\mathrm{P}$ & M & $\mathrm{N} \times \mathrm{P}$ & $\mathrm{N} \times \mathrm{M}$ & $\mathrm{P} \times \mathrm{M}$ & $\mathrm{N} \times \mathrm{P} \times \mathrm{M}$ \\
\hline \multirow{5}{*}{$0-20$} & SOC & 0.669 & 0.254 & 0.000 & 0.283 & 0.288 & 0.019 & 0.299 \\
\hline & $\mathrm{F} 1$ & 0.008 & 0.088 & 0.000 & 0.230 & 0.398 & 0.076 & 0.072 \\
\hline & $\mathrm{F} 2$ & 0.664 & 0.442 & 0.000 & 0.232 & 0.310 & 0.330 & 0.090 \\
\hline & F3 & 0.919 & 0.003 & 0.001 & $0.010^{*}$ & $0.003^{*}$ & $0.000^{*}$ & 0.294 \\
\hline & $\mathrm{F} 4$ & 0.223 & 0.953 & 0.024 & 0.298 & $0.025^{*}$ & 0.695 & $0.036^{*}$ \\
\hline \multirow{5}{*}{$20-40$} & SOC & 0.278 & 0.112 & 0.000 & 0.415 & 0.667 & 0.407 & 0.894 \\
\hline & F1 & 0.924 & 0.155 & 0.000 & 0.750 & 0.286 & 0.360 & 0.329 \\
\hline & $\mathrm{F} 2$ & 0.528 & 0.528 & 0.003 & 0.377 & $0.033^{*}$ & 0.935 & 0.508 \\
\hline & F3 & 0.757 & 0.107 & 0.757 & 0.482 & 0.509 & 0.791 & 0.146 \\
\hline & F4 & 0.108 & 0.173 & 0.057 & 0.540 & 0.114 & 0.254 & 0.095 \\
\hline
\end{tabular}

Note: ${ }^{*}$ indicates significance at $P<0.05$ level.
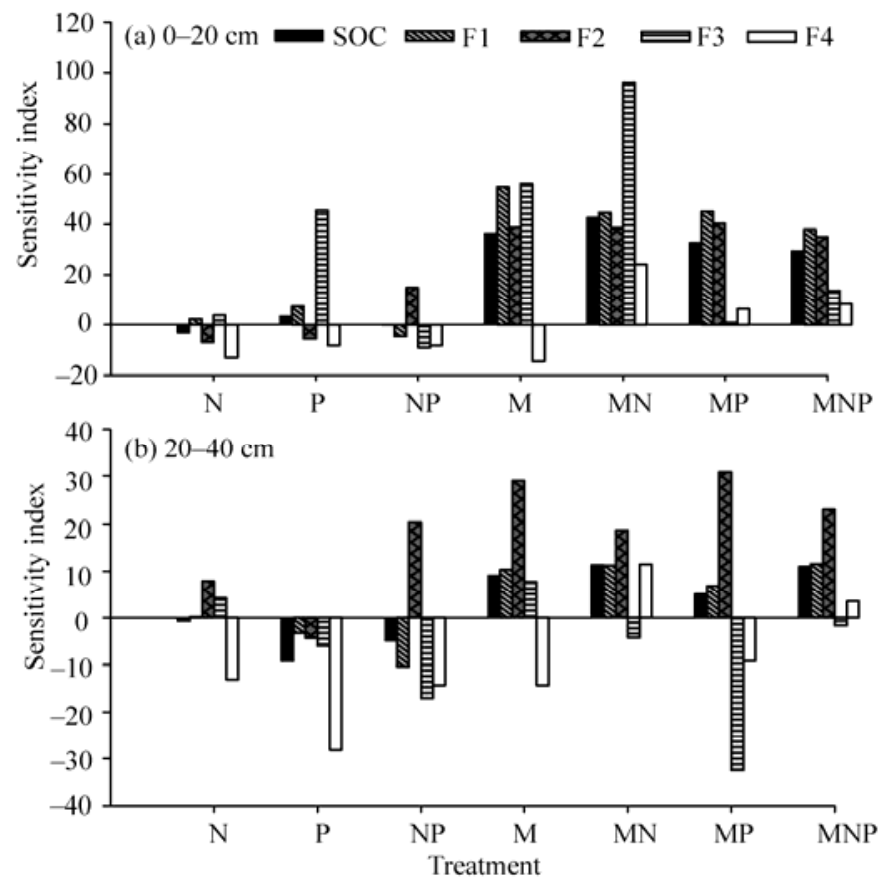

Fig. 2 Comparison the sensitivity of OOC fractions and SOC in the 0-20 (a) and 20-40 cm (b) soil layers under different fertilization treatments

\subsection{The carbon content and OOC fractions after 15-year fertilization}

After 15-year cultivation with different fertilization, the SOC contents increased in all fertilization treatments in the $0-20 \mathrm{~cm}$ layer, while the average increase level was different in 
inorganic fertilizer and organic manure, $11 \%$ and 50\%, respectively (Fig. 3). As for OOC fractions, the average increases of F1, F2, F3 and F4 were $5 \%, 16 \%, 4 \%$ and $24 \%$ in the treatment with inorganic fertilizer and $50 \%, 60 \%, 29 \%$ and $46 \%$ in the treatment with organic manure, respectively. On the whole, organic fertilizer increased greater than inorganic fertilizer in different fractions. While in the $20-40 \mathrm{~cm}$ layer, carbon content with inorganic fertilizer decreased in most fractions except in F4, which increased in all treatments, and the average increases for inorganic fertilizer and organic manure were $29 \%$ and $55 \%$, respectively. For the soil with organic fertilizer, the carbon content of SOC, F1 and F2 increased about $8 \%$, by contrast, $\mathrm{F} 3$ decreased by $40 \%$ averagely in all treatments.

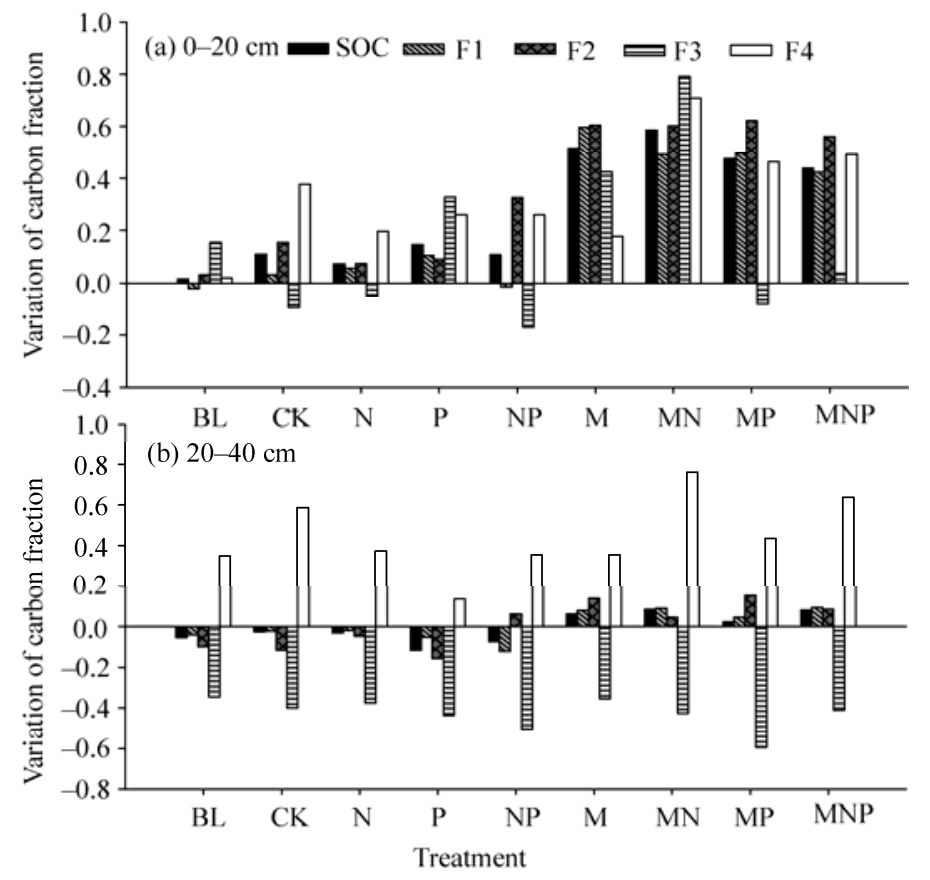

Fig. 3 Variation of the carbon fractions in the 0-20 (a) and 20-40 cm (b) soil layers after 15-year fertilization

\subsection{Carbon management index}

Carbon management index (CMI) is an important index for evaluating the changes in $\mathrm{C}$ status. CMI was significantly higher in the $0-20 \mathrm{~cm}$ layer in the treatments containing manure than in those with inorganic fertilizer (Table 4) and was highest in $\mathrm{M}$ treatment (174.16). CMI did not

Table 4 The values of CPI, L, LI and CMI under different treatments

\begin{tabular}{|c|c|c|c|c|c|c|c|c|}
\hline \multirow{2}{*}{ Index } & \multicolumn{4}{|c|}{$0-20 \mathrm{~cm}$} & \multicolumn{4}{|c|}{$20-40 \mathrm{~cm}$} \\
\hline & CPI & $\mathrm{L}$ & LI & CMI & CPI & $\mathrm{L}$ & LI & CMI \\
\hline $\mathrm{BL}$ & $0.92^{\mathrm{d}}$ & $0.87^{\mathrm{bc}}$ & $1.07^{\mathrm{bc}}$ & $97.96^{\mathrm{cd}}$ & $0.97^{\mathrm{cd}}$ & $0.87^{\mathrm{ab}}$ & $1.02^{\mathrm{abc}}$ & $98.56^{\mathrm{ab}}$ \\
\hline $\mathrm{N}$ & $0.97^{\text {cd }}$ & $0.90^{\mathrm{bc}}$ & $1.11^{\mathrm{bc}}$ & $107.56^{\mathrm{cd}}$ & $0.99^{\mathrm{bcd}}$ & $0.86^{\mathrm{abc}}$ & $1.01^{\mathrm{abc}}$ & $100.74^{\mathrm{a}}$ \\
\hline $\mathrm{P}$ & $1.03^{\mathrm{c}}$ & $0.87^{\mathrm{bc}}$ & $1.07^{\mathrm{bc}}$ & $110.96^{c}$ & $0.91^{\mathrm{d}}$ & $0.96^{\mathrm{a}}$ & $1.12^{\mathrm{a}}$ & $102.11^{\mathrm{a}}$ \\
\hline NP & $1.00^{\text {cd }}$ & $0.75^{\mathrm{d}}$ & $0.93^{\mathrm{d}}$ & $92.38^{\mathrm{d}}$ & $0.95^{\mathrm{cd}}$ & $0.76^{\mathrm{c}}$ & $0.90^{\mathrm{c}}$ & $85.27^{\mathrm{ab}}$ \\
\hline M & $1.36^{\mathrm{ab}}$ & $1.03^{\mathrm{a}}$ & $1.28^{\mathrm{a}}$ & $174.16^{\mathrm{a}}$ & $1.09^{\mathrm{ab}}$ & $0.87^{\mathrm{ab}}$ & $1.02^{\mathrm{ab}}$ & $111.15^{\mathrm{a}}$ \\
\hline $\mathrm{MN}$ & $1.43^{\mathrm{a}}$ & $0.83^{\mathrm{cd}}$ & $1.03^{\mathrm{cd}}$ & $146.67^{\mathrm{b}}$ & $1.11^{\mathrm{a}}$ & $0.85^{\mathrm{bc}}$ & $1.00^{\mathrm{bc}}$ & $110.90^{\mathrm{a}}$ \\
\hline MP & $1.33^{\mathrm{b}}$ & $0.96^{\mathrm{ab}}$ & $1.18^{\mathrm{ab}}$ & $157.04^{\mathrm{b}}$ & $1.05^{\mathrm{abc}}$ & $0.88^{\mathrm{ab}}$ & $1.03^{\mathrm{ab}}$ & $108.21^{\mathrm{a}}$ \\
\hline MNP & $1.30^{\mathrm{b}}$ & $0.91^{\mathrm{bc}}$ & $1.13^{\mathrm{bc}}$ & $145.94^{b}$ & $1.11^{\mathrm{a}}$ & $0.86^{\mathrm{bc}}$ & $1.01^{\mathrm{bc}}$ & $111.85^{\mathrm{a}}$ \\
\hline
\end{tabular}

Note: Means with the same letter within a column are not significantly different at $P<0.05$ level. CPI, carbon pool index; L, lability; LI, lability index; CMI, carbon management index. 
differ significantly in the $20-40 \mathrm{~cm}$ layer between the treatments containing manure and those containing inorganic fertilizer.

\subsection{Relationships between the OOC fractions and soil properties}

We conducted correlation analysis for better understanding the relationship between OOC fractions and soil physical-chemical properties (Table 5). All OOC fractions were highly correlated with SOC. F1 and F2 were highly correlated with TN and AN; F3 was negatively correlated with $\mathrm{pH}$ and $\mathrm{F} 4$ was weakly correlated with $\mathrm{TN}$.

Table 5 Correlation coefficient between OOC fractions and soil properties

\begin{tabular}{|c|c|c|c|c|c|c|c|c|c|c|}
\hline & SOC & F1 & F2 & F3 & F4 & TN & $\mathrm{TP}$ & $\mathrm{AN}$ & AP & $\mathrm{pH}$ \\
\hline SOC & 1.00 & & & & & & & & & \\
\hline $\mathrm{F} 1$ & $0.96^{* *}$ & 1.00 & & & & & & & & \\
\hline $\mathrm{F} 2$ & $0.91^{* *}$ & $0.84^{* *}$ & 1.00 & & & & & & & \\
\hline F3 & $0.50^{* *}$ & $0.49^{*}$ & 0.22 & 1.00 & & & & & & \\
\hline F4 & $0.62^{* *}$ & $0.44^{*}$ & $0.52^{* *}$ & 0.20 & 1.00 & & & & & \\
\hline $\mathrm{TN}$ & $0.88^{* *}$ & $0.88^{* *}$ & $0.89^{* *}$ & 0.33 & $0.38^{*}$ & 1.00 & & & & \\
\hline $\mathrm{TP}$ & 0.25 & 0.23 & 0.31 & -0.27 & 0.31 & 0.30 & 1.00 & & & \\
\hline $\mathrm{AN}$ & $0.81^{* *}$ & $0.83^{* *}$ & $0.79^{* *}$ & 0.38 & 0.28 & $0.84^{* *}$ & 0.13 & 1.00 & & \\
\hline $\mathrm{AP}$ & 0.35 & 0.35 & $0.43^{*}$ & -0.29 & 0.30 & $0.42^{*}$ & $0.88^{* *}$ & 0.33 & 1.00 & \\
\hline $\mathrm{pH}$ & -0.18 & -0.21 & 0.06 & $-0.60^{* *}$ & -0.05 & -0.03 & 0.05 & 0.03 & 0.14 & 1.00 \\
\hline
\end{tabular}

Note: ${ }^{*}$ and ${ }^{* *}$ indicate significant correlations at $P<0.05$ and $P<0.01$ levels, respectively; $n=27$. SOC, soil organic carbon; F1-F4 indicate the fractions of OOC; TN, total nitrogen; TP, total phosphorous; AN, available nitrogen; AP, available phosphorous.

\subsection{Cluster analysis}

The results of the cluster analysis with the OOC fractions and SOC as variables are shown in Fig. 4. The analysis identified two groups, one containing $\mathrm{CK}, \mathrm{BL}, \mathrm{N}, \mathrm{P}$, and NP and the other containing the treatments with manure. In addition to $\mathrm{BL}$ and $\mathrm{CK}$, the cluster analysis thus indicated a significant difference between the inorganic and organic fertilizations.

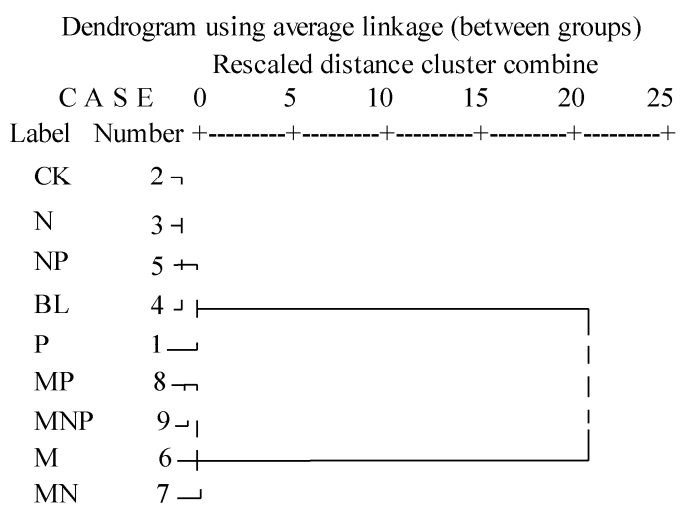

Fig. 4 Cluster analysis for different treatments

\section{Discussion}

\subsection{SOC}

Cultivation over 15 years did not cause a significant decrease in SOC content (CK-BL; Table 2), which is inconsistent with the result of Majumder et al. (2007) in India. Variations in the rate of decomposition of crop residues in soils under different climatic conditions (semi-arid vs 
sub-tropic) might be responsible for such differences (Majumder et al., 2008). The BL soil did not change significantly over the years without the input of organic matter; its fertility was mainly maintained by a relative dynamic balance. Also, the corn in CK treatment consumed some nutrients, and its roots generate more root exudates or crop residues for conversion to SOM by biochemical decomposition and microbial activity (Wander, 2004).

SOC content increased more with organic than inorganic fertilization. SOC content did not differ significantly between $\mathrm{CK}$ and the treatments containing only inorganic fertilizer, indicating that application of inorganic fertilizer did not contribute to SOC stabilization in the soil, as previously reported (Lou et al., 2011). The lowest SI under P treatment also confirmed this result. SOC content, though, increased significantly relative to $\mathrm{CK}$ with a combination of manure and $\mathrm{N}$ or $\mathrm{P}$ even with manure alone (Blair et al., 2006). The sheep manure in our study contained abundant nutrients, including $24 \% \mathrm{SOM}, 0.923 \% \mathrm{~N}, 0.167 \% \mathrm{P}$ and $2.669 \%$ potassium. In addition to the high input of organic fertilizer, the crops in these treatments had strong and extensive root systems, so an increase in nutrient supply by the addition of fertilizers would increase crop residues in the form of roots and stubble, which in turn would increase the SOC content (Malhi and Gill, 2002; Sherrod et al., 2005). Fertilization with manure for 15 years in our study increased SOC content by $35 \%$ compared to CK. While Blair et al. (2006) reported a $47 \%$ increase in conventional tillage as a result of the highest farmyard manure applications compared with the control during 96-year of a static experiment Kirchmann and Gerzabek (1999) reported a $75 \%$ increase in conventional tillage with the application of animal manure for 41-year compared with no fertilizer for the Ultano, long-term experiment in Sweden. These studies showed that such an increase in SOC levels is directly linked to the time of fertilization. SOC content in our study was highest with a combination of manure and $\mathrm{N}$ fertilizer, which demonstrated that $\mathrm{N}$ fertilizer is indispensable to soil fertility, and was consistent with the results reported by Purakayastha et al. (2008).

\subsection{OOC fractions}

OOC did not differ significantly between inorganic fertilization and CK, either in the $0-20$ or 20-40 cm soil layer. The four fractions of OC extracted under a gradient of oxidizing conditions significantly differed among the treatments (Table 2), with proportions following the order F1 $(47 \%)>\mathrm{F} 2(27 \%)>\mathrm{F} 4(18 \%)>\mathrm{F} 3(8 \%)$. Chan et al. (2001), comparing the effectiveness of different pasture species in maintaining labile pools of SOC, reported a relatively high proportion $(65 \%)$ of TOC in the F1 and F2 pools in semi-arid areas of Australia, and Majumder (2007) reported that of $56.1 \%$ in India. For our result the TOC was higher, ranging from $70 \%$ to $79 \%$. The probable reason may assume two aspects. The manure in our experiment contained a lot of labile matter, leading directly to high F1 and F2 contents. On the other hand, due to dry climate condition, SOM was easily to be decomposed, which means that its labile fractions were higher than passive pool. Namely its passive pool or stabilized C is relatively low. Variations in the rate of decomposition of crop residues under different climatic conditions may contribute to the differences in the magnitude of the pools (Maia et al., 2007).

Chan et al. (2001) observed that most differences in soil quality among pastures were in the more easily oxidizable fractions (F1), and only small differences were found in other fractions. F1 contained a quickly reactive labile organic matter, which provides energy and nutrients for soil micro-organisms and releases part of the nutrients for plant usage with a short-term turnover. Its half-life is between days and few years (Strosser, 2010). The result that F1 percentage in M treatment in our study $(51 \%)$ was significantly higher than other treatments also confirmed his view and indicated that application of manure fertilizer could increase F1 fraction (Bhattacharyya et al., 2011). While F1 percentage decreased in NP treatment, the reason was that crop under this treatment grew fast and consumed lots of labile matter, without exogenous labile matter input, and then its F1 fraction decreased somehow (Soon et al., 2009). Majumder et al. (2008) reported that F1 was highly correlated with the production of corn and rice and concluded that F1 could be considered as a good indicator of the sustainability of a crop system. The higher variations in F1 in our study demonstrated that it can be used as an indicator for monitoring the changes in SOC 
quality in agricultural systems.

Our result also indicated that long-term fertilization with inorganic fertilizer increased F4 fraction, especially obvious in deeper soil. This result suggests that recalcitrant fraction tended to stabilize in deeper layer and was consistent with the result of Ghosh et al. (2010). However, this speculation needs to be verified in future study. F4 is the most resistant soil fraction and is known as the "passive component" in the simulation models of SOM. The turnover time of the passive pool, which is inert, is about 2,000 years. The labile pool is thus a more sensitive indicator than the passive pool of changes in SOC resulting from different management practices (Chan et al., 2001).

\subsection{CMI evaluation}

Low CMI values $(<100)$ indicate a negative impact of a management practice on SOC content and soil quality (Blair et al., 1995). The values of CMI in the study were greater than 100 in the $0-20$ $\mathrm{cm}$ layer for the treatments containing manure but were lower in both layers for the treatments with inorganic fertilizer. The cluster analysis result also confirmed this difference. Blair et al. (2006) reported that fertilization with manure and manure combined with an inorganic fertilizer significantly increased CMI value relative to other chemical fertilizer treatments in a long-term experiment. Gong et al. (2009) also reported that 18-year of organic manure addition (alone and in combination with $\mathrm{N}$ fertilizer) was more effective for increasing CMI than chemical fertilizer alone in a wheat-maize system.

\section{Conclusions}

The study demonstrated that applications of manure fertilizer increased SOC content much more than inorganic fertilizer in agricultural soils, and differences in fertilization significantly influenced SOC pool at the surface layer. And fertilization time is an important factor to determine SOC content. The labile fractions (F1 and F2) showed advantages in quantity over passive fractions $(\mathrm{F} 3+\mathrm{F} 4)$ in this region. $\mathrm{F} 1$ was a more sensitive index than the other $\mathrm{C}$ fractions through SI analysis, and could reflect the labile $\mathrm{C}$ fractions changes. Long-term fertilization with inorganic fertilizer could increase F4 fraction and F4 tend to be stabilized in deeper soil layers. The manure fertilizer not only increased labile fractions (F1) in a short time, but also increased passive fraction (F4) in a long term. The mixed fertilizer mainly influenced F3. Farmland on the Loess Plateau thus should use more manure fertilizer for the long-term soil sustainability.

\section{Acknowledgements}

This study was supported by the National Natural Science Foundation of China (41371510, 41371508, 41471438) and the Science and Technology Research and Development Plan of Shaanxi Province (2011KJXX36). We appreciate the reviewers' comments for improving this manuscript.

\section{References}

Banger K, Toor G S, Biswas A, et al. 2010. Soil organic carbon fractions after 16-years of applications of fertilizers and organic manure in a Typic Rhodalfs in semi-arid tropics. Nutrient Cycling in Agroecosystems, 86(3): 391-399.

Barreto P A B, Gama-Rodrigues E F, Gama-Rodrigues A C, et al. 2011. Distribution of oxidizable organic C fractions in soils under cacao agroforestry systems in Southern Bahia, Brazil. Agroforestry Systems, 81(3): 213-220.

Bhattacharyya R, Kundu S, Srivastva A K, et al. 2011. Long term fertilization effects on soil organic carbon pools in a sandy loam soil of the Indian sub-Himalayas. Plant and Soil, 341(1-2): 109-124.

Blair G J, Lefroy R D B, Lisle L. 1995. Soil carbon fractions based on their degree of oxidation, and the development of a carbon management index for agricultural systems. Australian Journal of Agricultural Research, 46(7): 1459-1466.

Blair N, Faulkner R D, Till A, et al. 2006. Long-term management impacts on soil C, N and physical fertility: Part II: Bad Lauchstadt static and extreme FYM experiments. Soil and Tillage Research, 91(1-2): 39-47.

Bolinder M A, Angers D A, Gregorich E G, et al. 1999. The response of soil quality indicators to conservation management. Canadian Journal of Soil Science, 79(1): 37-45. 
Campbell C A, McConkey B G, Zentner R P, et al. 1996. Long-term effects of tillage and crop rotations on soil organic C and total $\mathrm{N}$ in a clay soil in southwestern Saskatchewan. Canadian Journal of Soil Science, 76(3): 395-401.

Chan K Y, Bowman A, Oates A. 2001. Oxidizible organic carbon fractions and soil quality changes in an oxic paleustalf under different pasture leys. Soil Science, 166(1): 61-67.

Chan K Y, Heenan D P, Oates A. 2002. Soil carbon fractions and relationship to soil quality under different tillage and stubble management. Soil and Tillage Research, 63(3-4): 133-139.

Editorial Committee. 1996. Soil Physical and Chemical Analysis and Description of Soil Profiles. Beijing: Standards Press of China. (in Chinese)

Fan T L, Xu M G, Song S Y, et al. 2008. Trends in grain yields and soil organic C in a long-term fertilization experiment in the China Loess Plateau. Journal of Plant Nutrition and Soil Science, 171(3): 448-457.

Gong W, Yan X Y, Wang J Y, et al. 2009. Long-term manuring and fertilization effects on soil organic carbon pools under a wheat-maize cropping system in North China Plain. Plant and Soil, 314(1-2): 67-76.

Guareschi R F, Pereira M G, Perin A. 2013. Oxidizable carbon fractions in Red Latosol under different management systems. Revista Ciência Agronômica, 44(2): 242-250.

Ghosh S, Wilson B R, Mandal B, et al. 2010. Changes in soil organic carbon pool in three long-term fertility experiments with different cropping systems and inorganic and organic soil amendments in the eastern cereal belt of India. Australian Journal of Soil Research, 48(5): 413-420.

He N, Lin Z. 1992. Effect of organic and chemical fertilizers on grain yields and soil properties. In: Proceedings of International Symposium on Nutrient Management for Sustained Productivity. Ludhiana: Department of Soil, Punjab Agricultural University, 2: 130-132.

Janzen H H, Campbell C A, Ellert B H, et al. 1997. Soil organic matter dynamics and their relationship to soil quality. Developments in Soil Science, 25: 277-292.

Kirchmann H, Gerzabek M H. 1999. Relationship between soil organic matter and micropores in a long-term experiment at Ultuna, Sweden. Journal of Plant Nutrition and Soil Science, 162(5): 493-498.

Lefroy R D B, Blair G J, Strong W M. 1993. Changes in soil organic matter with cropping as measured by organic carbon fractions and ${ }^{13} \mathrm{C}$ natural isotope abundance. In: Barrow N J. Plant Nutrition-from Genetic Engineering to Field Practice., Netherlands: Springer, 551-554.

Liu X, Li F M, Liu D Q, et al. 2010. Soil organic carbon, carbon fractions and nutrients as affected by land use in semi-arid region of Loess Plateau of China. Pedosphere, 20(2): 146-152.

Loss A, Moraes A D L, Pereira M G, et al. 2010. Carbon, light organic matter and oxidizable organic carbon fractions in different organic production systems. Comunicata Scientiae, 1(1): 57-64.

Lou Y L, Wang J K, Liang W J. 2011. Impacts of 22-year organic and inorganic N managements on soil organic C fractions in a maize field, northeast China. Catena, 87(3): 386-390.

Maia S M F, Xavier F A S, Oliveira T S, et al. 2007. Organic carbon pools in a Luvisol under agroforestry and conventional farming systems in the semi-arid region of Ceará, Brazil. Agroforestry Systems, 71(2): 127-138.

Majumder B, Mandal B, Bandyopadhyay P K, et al. 2007. Soil organic carbon pools and productivity relationships for a 34 year old rice-wheat-jute agroecosystem under different fertilizer treatments. Plant and Soil, 297(1-2): 53-67.

Majumder B, Mandal B, Bandyopadhyay P K. 2008. Soil organic carbon pools and productivity in relation to nutrient management in a 20-year-old rice-berseem agroecosystem. Biology and Fertility of Soils, 44(3): 451-461.

Malhi S S, Gill K S. 2002. Fertilizer N and P effects on root mass of bromegrass, alfalfa and barley. Journal of Sustainable Agriculture, 19(3): 51-63.

Patra D D, Chand S, Anwar M. 2014. Organic C dynamics and its conservation under wheat (Triticum aesetivum)-Mint (Mentha arvensis)-Sesbania rostrata cropping in sub-tropical condition of northern Indo-Gangetic plains. Journal of Environmental Management, 135: 118-125.

Pereira F B, Santos R C, Lombardi K C, et al. 2013. Soil oxidizable organic carbon fractions under organic management with industrial residue of roasted mate tea. In: Xu J M, Wu J J, He Y. Functions of Natural Organic Matter in Changing Environment. Netherlands: Springer, 295-299.

Purakayastha T J, Rudrappa L, Singh D, et al. 2008. Long-term impact of fertilizers on soil organic carbon pools and sequestration rates in maize-wheat-cowpea cropping system. Geoderma, 144(1-2): 370-378.

Rasmussen P E, Goulding K W T, Brown J R, et al. 1998. Long-term agroecosystem experiments: Assessing agricultural sustainability and global change. Science, 282(5390): 893-896.

Sherrod L A, Peterson G A, Westfall D G, et al. 2005. Soil organic carbon pools after 12 years in no-till dryland agroecosystems. Soil Science Society of America Journal, 69(5): 1600-1608. 
Shi H, Shao M A. 2000. Soil and water loss from the Loess Plateau in China. Journal of Arid Environments, 45(1): 9-20.

Soil Science Society of China. 1999. Soil Physical and Chemical Analysis. Beijing: Agricultural Science and Technology. (in Chinese)

Soon Y K, Haq A, Arshad M A. 2009. Carbon and nitrogen contents of different-sized light fraction organic matter as influenced by tillage and residue management. Canadian Journal of Soil Science, 89(3): 281-286.

Stevenson F J. 1994. Humus Chemistry: Genesis, Composition, Reactions ( $2^{\text {nd }}$ ed.). New York: John Wiley \& Sons.

Strosser E. 2010. Methods for determination of labile soil organic matter: an overview. Journal of Agrobiology, 27(2): 49-60.

Verma B C, Datta S P, Rattan R K, et al. 2010. Monitoring changes in soil organic carbon pools, nitrogen, phosphorus, and sulfur under different agricultural management practices in the tropics. Environmental Monitoring and Assessment, 171(1-4): 579-593.

Walkley A, Black I A. 1934. An examination of the Degtjareff method for determining soil organic matter, and a proposed modification of the chromic acid titration method. Soil Science, 37(1): 29-38.

Walkley A. 1947. A critical examination of a rapid method for determining organic carbon in soils-effect of variations in digestion conditions and of inorganic soil constituents. Soil Science, 63(4): 251-264.

Wander M. 2004. Soil organic matter fractions and their relevance to soil function. In: Magdoff F, Weil R R. Soil Organic Matter in Sustainable Agriculture. Boca Raton, FL: CRC Press, 67-102.

Wang B, Xue S, Liu G B, et al. 2012. Changes in soil nutrient and enzyme activities under different vegetations in the Loess Plateau area, Northwest China. Catena, 92: 186-195.

Wang Q K, Wang S L. 2011. Response of labile soil organic matter to changes in forest vegetation in subtropical regions. Applied Soil Ecology, 47(3): 210-216.

Xavier F A D S, Maia S M F, de Oliveira T S, et al. 2009. Soil organic carbon and nitrogen stocks under tropical organic and conventional cropping systems in Northeastern Brazil. Communications in Soil Science and Plant Analysis, 40(19-20): 2975-2994.

Yang S M, Li F M, Suo D R, et al. 2006. Effect of long-term fertilization on soil productivity and nitrate accumulation in Gansu Oasis. Agricultural Sciences in China, 5(1): 57-67.

Zhang C, Liu G B, Xue S, et al. 2011. Rhizosphere soil microbial activity under different vegetation types on the Loess Plateau, China. Geoderma, 161(3-4): 115-125.

Zhang C, Liu G B, Xue S, et al. 2013. Soil organic carbon and total nitrogen storage as affected by land use in a small watershed of the Loess Plateau, China. European Journal of Soil Biology, 54: 16-24.

Zhang L H, Xie Z K, Zhao R F, et al. 2012. The impact of land use change on soil organic carbon and labile organic carbon stocks in the Longzhong region of Loess Plateau. Journal of Arid Land, 4(3): 241-250. 